\title{
Changes in gene expression of DOR and other thyroid hormone receptors in rat liver during acute-phase response
}

\author{
Ihtzaz Ahmed Malik • Bernhard G. Baumgartner • \\ Naila Naz • Nadeem Sheikh • Federico Moriconi • \\ Giuliano Ramadori
}

Received: 15 August 2010 /Accepted: 15 September 2010/Published online: 15 October 2010

(C) The Author(s) 2010. This article is published with open access at Springerlink.com

\begin{abstract}
Non-thyroidal illness is characterized by low triiodothyronine (T3) serum level under acute-phase conditions. We studied hepatic gene expression of the newly identified thyroid hormone receptor (TR) cofactor DOR/ TP53INP2 together with TRs in a rat model of aseptic abscesses induced by injecting intramuscular turpentine-oil into each hind limb. A fast (4-6 h) decrease in the serum level of free thyroxine and free T3 was observed. By immunohistology, abundant DOR protein expression was detected in the nuclei of hepatocytes and ED- $1^{+}$(mononuclear phagocytes), CK- $19^{+}$(biliary cells), and $\mathrm{SMA}^{+}$(mesenchymal cells of the portal tract) cells. DOR signal was reduced with a minimum at 6-12 $\mathrm{h}$ after the acute-phase reaction (APR). Immunohistology also showed a similar pattern of protein expression in TR $\alpha 1$ but without a significant change during APR. Transcripts specific for DOR, nuclear receptor corepressor 1 (NCoR-1), and TR $\beta 1$ were down-regulated
\end{abstract}

Ihtzaz Ahmed Malik and Bernhard G. Baumgartner contributed equally to this work.

I. A. Malik • B. G. Baumgartner • N. Naz N. Sheikh •

F. Moriconi $\cdot$ G. Ramadori

Division of Gastroenterology and Endocrinology,

Department of Internal Medicine, University Medical Center,

Georg August University,

Göttingen, Germany

I. A. Malik ( $\square)$

Division of Gastroenterology and Endocrinology,

Department of Internal Medicine, University Medical Center,

Georg August University,

Robert-Koch Str. 40,

37075 Göttingen, Germany

e-mail: i.malik@med.uni-goettingen.de

Present Address:

B. G. Baumgartner

Department of Internal Medicine, University Hospital Göttingen,

Robert-Koch-Strasse 40,

37075 Göttingen, Germany with a minimum at 6-12 $\mathrm{h}$, whereas expression for $\mathrm{TR} \alpha 1$ and $T R \alpha 2$ was slightly and significantly up-regulated, respectively, with a maximum at $24 \mathrm{~h}$ after APR was initiated. In cultured hepatocytes, acute-phase cytokines interleukin-1 $\beta$ (IL-1 $\beta$ ) and IL-6 down-regulated DOR and TR $\beta 1$ at the mRNA level. Moreover, gene expression of DOR and TRs (TR $\alpha 1, T R \alpha 2$, and TR $\beta 1)$ was up-regulated in hepatocytes by adding $\mathrm{T} 3$ to the culture medium; this upregulation was almost completely blocked by treating the cells with IL-6. Thus, TR $\beta 1$, NCoR-1, and the recently identified DOR/TP53INP2 are abundantly expressed and down-regulated in liver cells during APR. Their downregulation is attributable to the decreased serum level of thyroid hormones and most probably also to the direct action of the main acute-phase cytokines.

Keywords Thyroid hormone - Thyroid hormone receptor. Cytokines $\cdot$ Acute phase response $\cdot$ Non-thyroidal-illness . Rat (Wistar)

$\begin{array}{ll}\text { Abbreviations } \\ \text { APP } & \text { Acute-phase protein } \\ \text { APR } & \text { Acute-phase reaction } \\ \text { cDNA } & \text { Complementary deoxyribonucleic acid } \\ \text { IL-1ß } & \text { Interleukin 1 beta } \\ \text { IL-6 } & \text { Interleukin 6 } \\ \text { LPS } & \text { Lipopolysaccharide } \\ \text { NCoR-1 } & \text { Nuclear receptor co-repressor } 1 \\ \text { NTI } & \text { Non-thyroidal illness } \\ \text { PBS } & \text { Phosphate-buffered saline } \\ \text { SMA } & \text { Smooth muscle actin } \\ \text { T3 } & \text { 3,3',5-triiodothyronine } \\ \text { T4 } & \text { Thyroxine } \\ \text { THs } & \text { Thyroid hormones } \\ \text { TR } & \text { Thyroid hormone receptor } \\ \text { TO } & \text { Turpentine oil }\end{array}$




\section{Introduction}

Acute-phase reaction (APR) is the response of the body to tissue injury. It is clinically characterized by fever, weakness, adynamia, somnolence, and loss of appetite. Leucocytosis, an increased erythrocyte sedimentation rate, dramatic changes in serum levels of acute-phase proteins, and a change in serum levels of several hormones are observed in the blood. In addition to the up-regulation of the serum level of corticosteroids, the concentration of thyroid hormones (THs) decreases (Bartalena et al. 1994). Metabolic changes during APR are attributable to the effects of interleukin (IL)-1-like beta (IL-1 $\beta$ ), tumor necrosis factor- $\alpha$, and IL-6-like cytokines (IL-6, oncostatin M, and others), through the activation of transcription factors, i.e., nuclear factor kappa B, activator protein 1 , signal transducer and activator of transcription $3 / 5$, or CCAAT/enhancer-binding protein $\beta$. These signaling cascades result in increased plasma levels of a number of positive acute-phase proteins (APPs), including clotting proteins, transport proteins, antiproteases, and complement factors, with a parallel decrease in negative APPs, such as albumin or transferrin (Ramadori and Christ 1999). Synthesis of the major APPs can be increased up to 1000 -fold over normal levels under acute-phase conditions. This group includes serum amyloid A and either Creactive protein in humans or its homolog in mice (Ramadori et al. 1985a) and alpha-2 macroglobulin in rat hepatocytes (Pierzchalski et al. 1992).

The state of altered $\mathrm{TH}$ metabolism observed under acute-phase conditions is called non-thyroidal illness (NTI), which is characterized by decreased serum TH levels (De Groot 1999). Indeed, during the acute-phase response induced by tissue injury, significant changes take place in the regulation of $\mathrm{TH}$ serum levels and in the molecules involved in signaling pathways. The mechanisms inducing the changes at various levels of synthesis and of THs (NTI) action during APR are still poorly defined. Although the possibility of inducing normal thyroxine (T4) and 3,3',5-triiodothyronine (T3) plasma levels in intensive-care patients through hormonal stimulation of the anterior pituitary gland has been shown (Van den Berghe et al. 1999), the changes observed during the acute phase might be part of the defense strategy of the body. Indeed, therapeutic administration of THs to intensive-care patients might improve metabolic parameters (Van den Berghe et al. 1999, 2002) but not the patient outcome (Becker et al. 1982; Brent and Hershman 1986).

$\mathrm{T} 3$, the biologically active form of $\mathrm{TH}$, plays a central role in metabolic homeostasis, development, cell differentiation, and growth under normal metabolic conditions (Fowden 1995; Yen 2001). THs act at the cellular level through diverse receptors. The gene expression of receptors is known to be dependent on the hormone level. T3 regulates gene expression by interacting with isoforms of the TH receptor (TR) derived from two different genes, viz., TR $\alpha$ and TR $\beta$ (Brent et al. 1989a, 1989b). TRs are differentially distributed in various tissues and during developmental stages, indicating distinct and specific functional roles. TR $\alpha$ is mainly present in the central nervous system and muscle but is also found in the liver (Amma et al. 2001; Ercan-Fang et al. 1996). In liver, two isoforms of TR $\alpha$ are present: the canonical TR $\alpha 1$ and the alternatively spliced TR $\alpha 2$, which lacks the T3-binding domain and therefore acts as the dominant negative inhibitor of TR $\alpha 1$ and TR $\beta 1$ at higher concentrations (Laudet et al. 1991). The predominant active form of TR in a murine liver cell line is TR $\beta 1$ (Ventura-Holman et al. 2007), but another report also underlines the important role of TR $\alpha$ in the liver (Macchia et al. 2001). In addition, TR $\alpha 2$ has been shown to have an inhibitory effect on the other TR isoforms (Koenig et al. 1989). Recent experiments with knockout mice have demonstrated that absence of both TR $\alpha \mathrm{s}$ or TR $\alpha 2$ alone results in a higher T3 sensitivity; this has been hypothesized to be attributable to the inhibitory effect of $\mathrm{TR} \alpha 2$, which is missing in these knockout mice (Macchia et al. 2001). Another TH corepressor protein, called nuclear receptor co-repressor 1 (NCoR-1; Horlein et al. 1995), is known to promote chromatin condensation and prevents access to the transcription machinery in the gene transcription regulated by the TR and retinoic X receptor (Grignani et al. 1998; Horlein et al. 1995).

Recently, a novel component of TH action, DOR/ TP53INP2, has been identified, which is repressed in diabetic rat muscle. DOR is localized within the nucleus and has been shown to be crucial for the transcriptional regulation of T3-controlled genes by direct interaction with $\mathrm{TR} \alpha 1$ (Baumgartner et al. 2007).

In the present study, we have demonstrated that the TRs are down-regulated in the liver and liver cells in a rat model of APR. This may be attributable not only to a reduced TH serum level, but also to the direct effect of acute-phase mediators on the regulation of the TR gene expression in liver cells, possibly explaining the lack of clinical effectiveness of $\mathrm{T} 3$ administration under acutephase conditions.

\section{Materials and methods}

Animals

Male Wistar rats of about 170-200 g body weight were purchased from Harlan-Winkelmann (Brochen, Germany). 
Table 1 Rat primer sequences used (TR thyroid hormone receptor, $N C o R$ nuclear receptor co-repressor, DOR TR co-factor, $U B C$ ubiquitin $\mathrm{C}$ )

\begin{tabular}{lll}
\hline Primer & $5^{\prime}-3^{\prime}$ Forward & $5^{\prime}-3^{\prime}$ Reverse \\
\hline TR $\alpha 1$ & TGCCCTTACTCACCCCTACA & AAGCCAAGCCAAGCTGTCCT \\
TR $\alpha 2$ & TGAGCAGCAGTTTGGGAAG & GAATGGAGAATTCCGCTTCG \\
TR $\beta 1$ & AGCCAGCCACAGCACAGTGA & CGCCAGAAGACTGAAGCTTGC \\
NCoR-1 & AGTCGCTACAGCCCAGAGTC & CTCCTCTCTGGGGATTTTCC \\
DOR & AACCACAGCCTGCTTCTAATACCTT & TCAGCCAGTCTCAACACAAAACAC \\
$\beta-A c t i n$ & ACCACCATGTACCCAGGCATT & CCACACAGAGTACTTGCGCTCA \\
UBC & CACCAAGAAGGTCAAACAGGAA & AAGACACCTCCCCATCAAACC \\
\hline
\end{tabular}

The rats were kept under standard conditions with $12 \mathrm{~h}$ light/dark cycles and ad libitum access to fresh water and food pellets. All animals were cared for according to the University's guidelines, the German convention for the protection of animals, and NIH guidelines.

\section{Antibodies}

A mouse monoclonal antibody directed against CK-19 (marker for biliary cells) was purchased from Novocastra (Newcastle upon Tyne, UK), a mouse monoclonal antibody directed against smooth muscle actin (SMA) from Sigma (Munich, Germany), a rabbit polyclonal anti-TR $\alpha 1$ from Abcam (Cambridge, UK), and a mouse anti-rat ED-1 (marker for mononuclear phagocytes) monoclonal antibody from Serotec (Duesseldorf, Germany). A rabbit polyclonal antibody directed against human DOR/TP53INP2 (a TR cofactor) was a gift from Prof. Antonio Zorzano (University of Barcelona, Spain). Detection by immunofluorescence was carried out as described previously (Malik et al. 2010).

\section{Induction of APR}

APR was induced in ether-anesthetized rats by intramuscular injection of $5 \mathrm{mg} / \mathrm{kg}$ turpentine oil (TO) into both the right and left hind limbs of the animals. Control animals were treated in the same way for each time-point with saline injection into both limbs. Animals were killed 0.5, 1 , $2,4,6,12,24,36,48,60$, and $72 \mathrm{~h}$ after TO injection under pentobarbital anesthesia. Livers were excised, rinsed with physiological sodium saline, snap-frozen in liquid nitrogen, and stored at $-80^{\circ} \mathrm{C}$ until further use.

Measurement of free thyroxine and free tri-iodothyronine levels

At time-points ranging from 1-24 $\mathrm{h}$ after TO injection, blood samples from the inferior vena cava were collected from controls and TO-injected rats and used for the detection of free thyroxine (FT4) and free triiodothyronine (FT3) levels in the serum of rats by using a standard protocol (University Medical Center, Göttingen).
Immunofluorescent staining

Double-immunofluorescence was performed according to a protocol described previously (Malik et al. 2010). Briefly, cryostat sections ( $\sim 5 \mu \mathrm{m}$ thick) were fixed in acetone for $10 \mathrm{~min}$. Afterwards, the rabbit polyclonal primary antibody against DOR and a mouse monoclonal anti-CK-19, a rabbit monoclonal anti- $\alpha$-SMA, and a mouse monoclonal anti-ED-1 primary antibody $(1: 50)$ were incubated with the sections overnight at $4^{\circ} \mathrm{C}$.

a

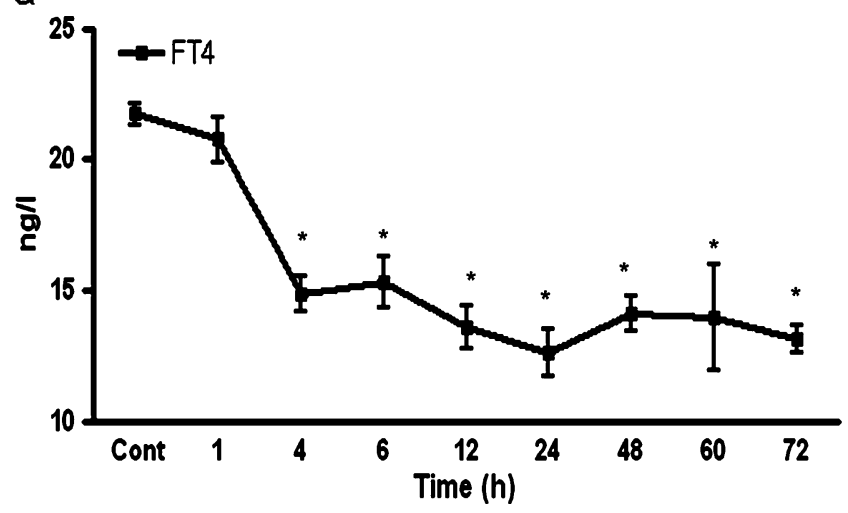

b



Fig. 1 Serum-free thyroxine $(F T 4 ;$ a) and free tri-iodothyronine (FT3; b) levels in rats during acute-phase reaction (APR). Values on the $y$ axis are serum concentration values of FT3 and FT4 measured compared with saline-treated controls. Results represent means \pm SEM of three animals; $* P<0.05$ 
Following a short washing step in phosphate-buffered saline (PBS), incubation was carried out with Alexa-Fluorconjugated goat anti-rabbit and anti-mouse secondary antibody (1:200; Molecular Probes, Germany) at room temperature for $1 \mathrm{~h}$. The sections were washed 3 times for $5 \mathrm{~min}$ in PBS. Finally, nuclei were stained with 4,6diamidino-2-phenylindole (DAPI), and sections were washed and mounted.

Protein isolation and Western blot analysis

Proteins were isolated as described previously (Tron et al. 2005). Livers at various time-points after TO treatment were lysed in hot Laemmli buffer $\left(95^{\circ} \mathrm{C}\right)$ and processed with sodium dodecyl sulphate polyacrylamide gel electrophoresis under reducing conditions according to (Laemmli 1970). The protein content of the cellular lysates was calculated by the Coomassie Protein Assay (Pierce,
Germany) in which $\beta$-actin was used as the loading control. Proteins were transferred onto Hybond-ECL nitrocellulose hybridization transfer membranes according to Towbin et al. (1979). We performed immunodetection studies according to the ECL Western blotting protocol of GE Healthcare (Germany). The primary antibody to DOR was used at a 1:100 dilution, whereas the anti-rabbit immunoglobulins were each used at a 1:2000 dilution.

Isolation of hepatocytes and culture conditions

Hepatocytes were isolated from normal animals according to Seglen (1972) with the modification as described in Ramadori et al. (1990). The purity of the isolated cell populations was determined by phase-contrast microscopy and by immunocytochemistry with antibodies against laminin or glial fibrillary acidic protein in order to identify stellate cells (both by Sigma, Germany) or ED-1 and ED-2
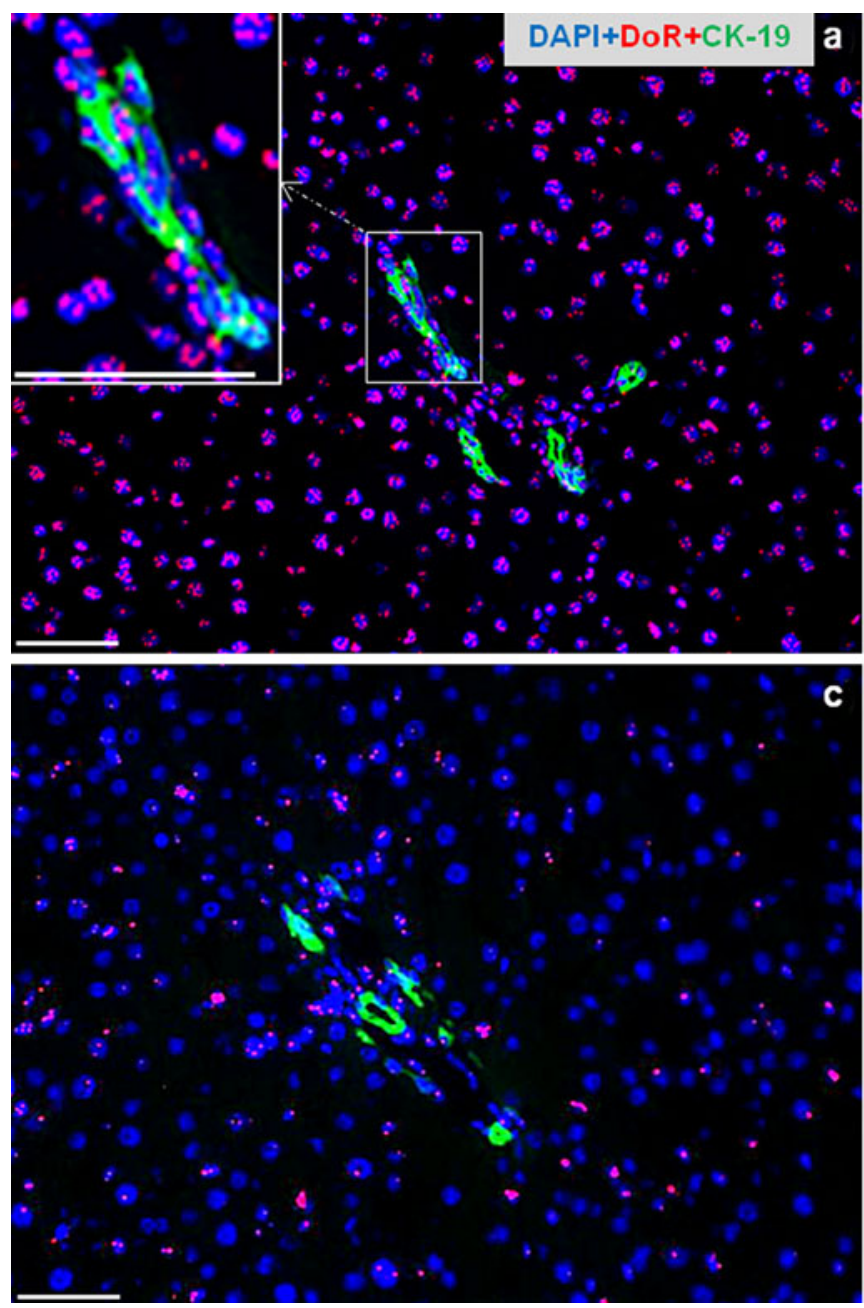

Fig. 2 Double-staining of liver sections with polyclonal antibody directed against DOR (red) and monoclonal antibody against human CK-19 (green) followed by fluorescence immunodetection in sections of rat liver during APR after TO treatment. a Control liver. Inset
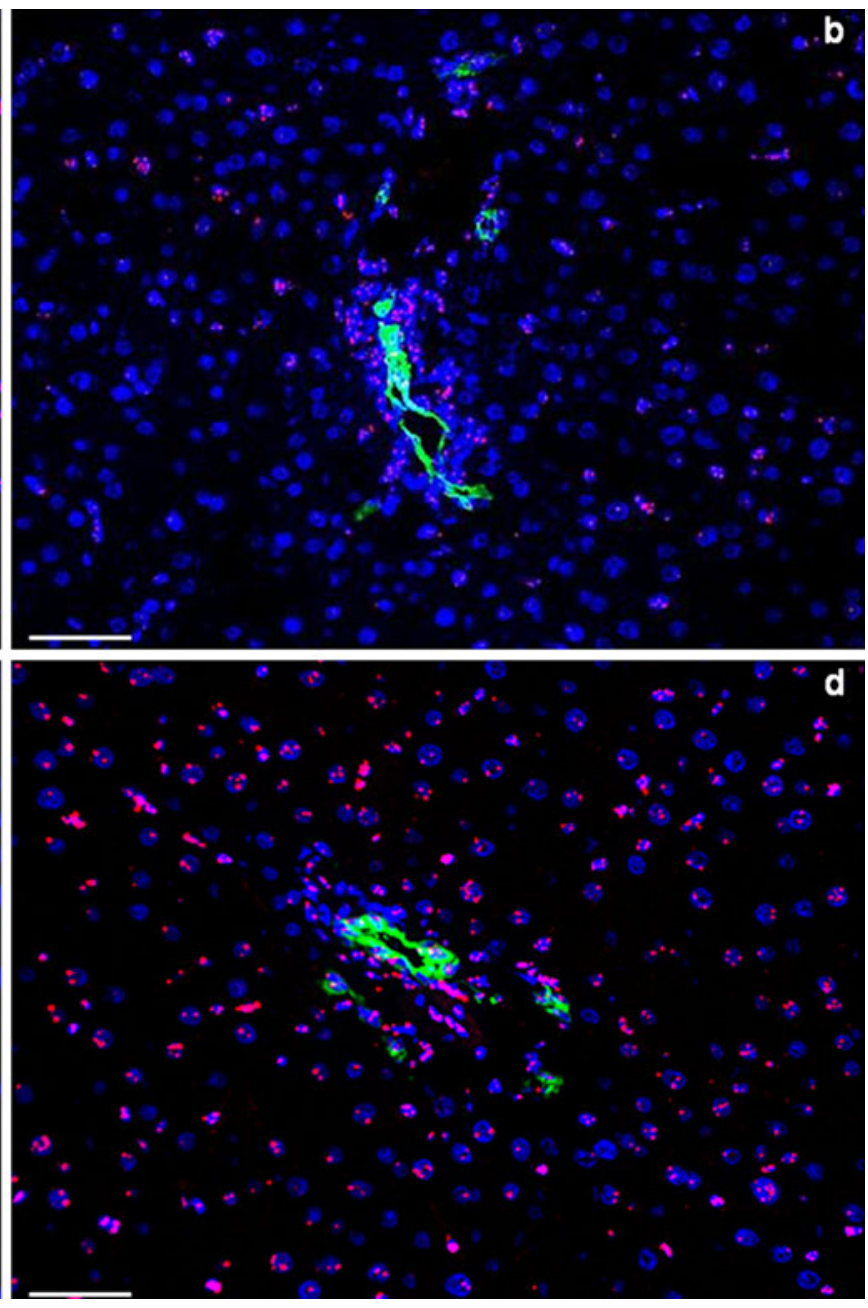

Higher magnification of boxed area in $\mathbf{a}$. b At $6 \mathrm{~h}$ after TO treatment. c At $12 \mathrm{~h}$ after TO treatment. d At 24 hours after TO treatment. Representive results from three animals and six slides per time-point. Original magnification: $\times 200$. Bars $100 \mu \mathrm{m}$ 
(gift from C. Dijkstra; Dijkstra et al. 1985) for macrophages. The cells were incubated at $37^{\circ} \mathrm{C}$ in a $95 \%$ air $/ 5 \%$ $\mathrm{CO}_{2}$ atmosphere. DMEM (Biochrom, Germany) was supplemented with 10\% fetal calf serum (PAA, Germany), $0.05 \%$ insulin (Roche, Germany), and $10^{-7}$ dexamethasone (Sigma, Germany). Hepatocytes were exposed to a single treatment of $100 \mathrm{ng} / \mathrm{ml}$ recombinant IL-6 and IL- $1 \beta$ (PeproTech, Germany) after a dose-dependent (10, 100, and $1000 \mathrm{ng} / \mathrm{ml}$ ) study at 6 and $12 \mathrm{~h}$ following stimulation, for both cytokines in $3 \mathrm{ml}$ cell-culture medium. Cells were also stimulated with $100 \mathrm{nM} \mathrm{T} 3$ in $3 \mathrm{ml}$ cell-culture medium in the presence or absence of IL-6 as described previously (Dace et al. 2000; Sheikh et al. 2006). Hepatocytes were harvested in all in vitro experiments at $1,3,6,12$, and $24 \mathrm{~h}$ after cytokine treatment. Non-treated cells at all studied time-points served as controls in all experiments.
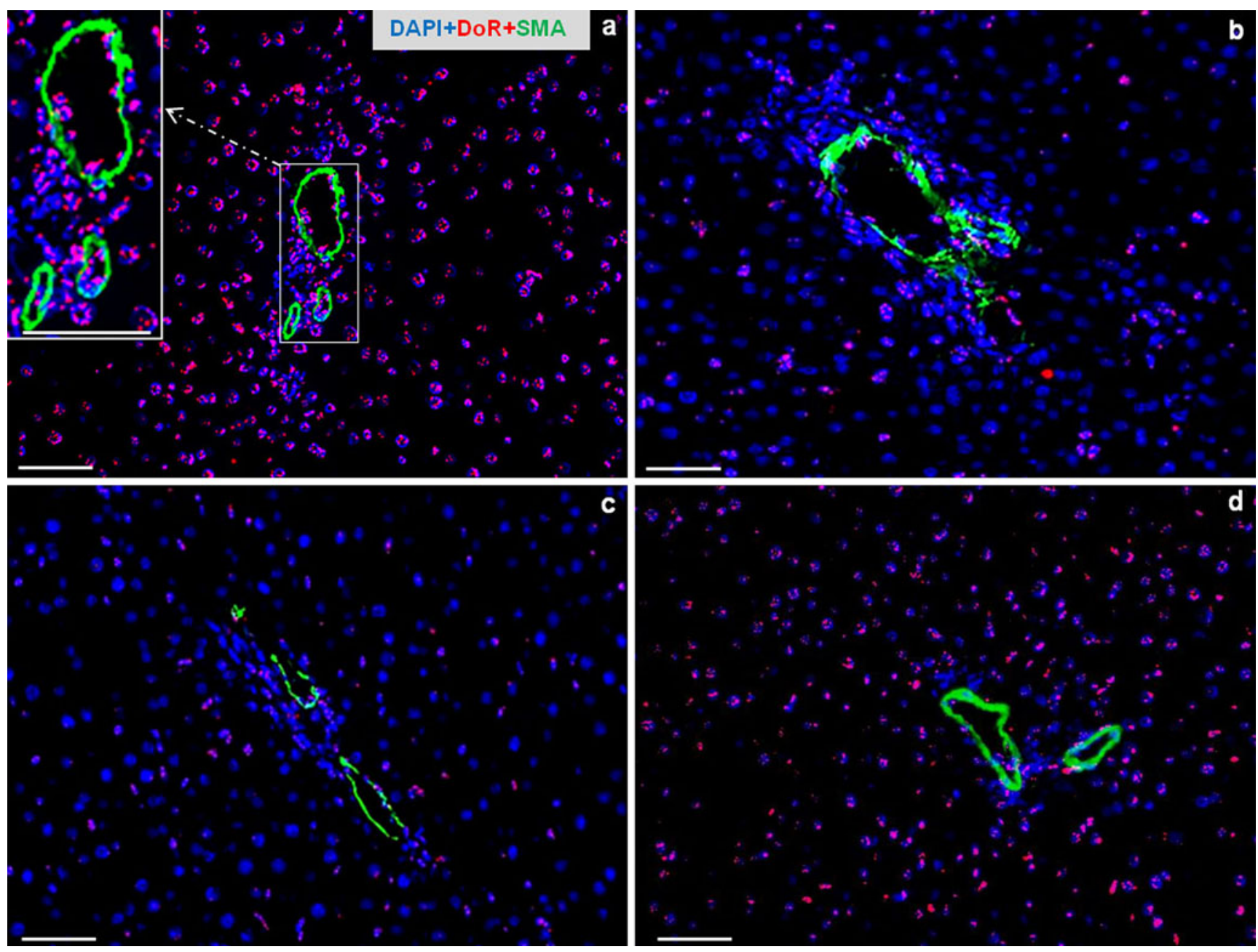

Fig. 3 Double-staining of liver sections with polyclonal antibody directed against DOR (red) and monoclonal antibody against human SMA (green) followed by fluorescent immunodetection in sections of rat liver during APR after TO treatment. a Control liver. Inset Higher magnification of boxed area in a. b At $6 \mathrm{~h}$ after TO treatment. c At
RNA isolation and quantitative real-time polymerase chain reaction

Total RNA was isolated from liver samples and hepatocytes by means of guanidine isothiocyanate extraction, caesium chloride density-gradient ultracentrifugation, and ethanol precipitation according to a previously described method (Chirgwin et al. 1979), with some modifications as described elsewhere (Ramadori et al. 1985b). The RNA obtained was quantified by measuring the absorbance at $260 \mathrm{~nm}$. cDNA was generated by reverse transcription of $1 \mathrm{mg}$ total RNA with $100 \mathrm{nM}$ dNTPs, 50 pM primer oligo(dT) $15,200 \mathrm{U}$ Moloney murine leukemia virus reverse transcriptase, $16 \mathrm{U}$ protector RNase inhibitor, $1 \times$ reverse transcription buffer, and $2.5 \mathrm{ml} 0.1 \mathrm{M}$ dithiothreitole for $1 \mathrm{~h}$ at $40^{\circ} \mathrm{C}$. Gene expression was analyzed by using Platinum SybrGreen qPCR mix UDG

$12 \mathrm{~h}$ after TO treatment. d At 24 hours after TO treatment. DORpositive cell numbers decreased in liver during APR. Representive results from three animals and six slides per time-point. Original magnification: $\times 200$. Bars $100 \mu \mathrm{m}$ 
(Invitrogen, Germany). The housekeeping genes ubiquitin $C(\mathrm{UBC})$ and $\beta$-actin were used as normalizers. The primer sequences used are shown in Table 1. Amplification was performed at $95-60^{\circ} \mathrm{C}$ for 45 cycles in an ABI prism 7000 sequence detection system. All samples were assayed in duplicate. The results were normalized to the housekeeping gene, and the fold-change in expression was calculated by using threshold cycle values.

\section{Statistical analysis}

The data were analyzed by using Prism Graph Pad 4 software (San Diego, USA). All experimental errors are shown as SEM. Statistical significance was calculated by Student's -test, one-way analysis of variance, and Dunnett's post hoc tests. Significance was accepted at $P<0.05$.
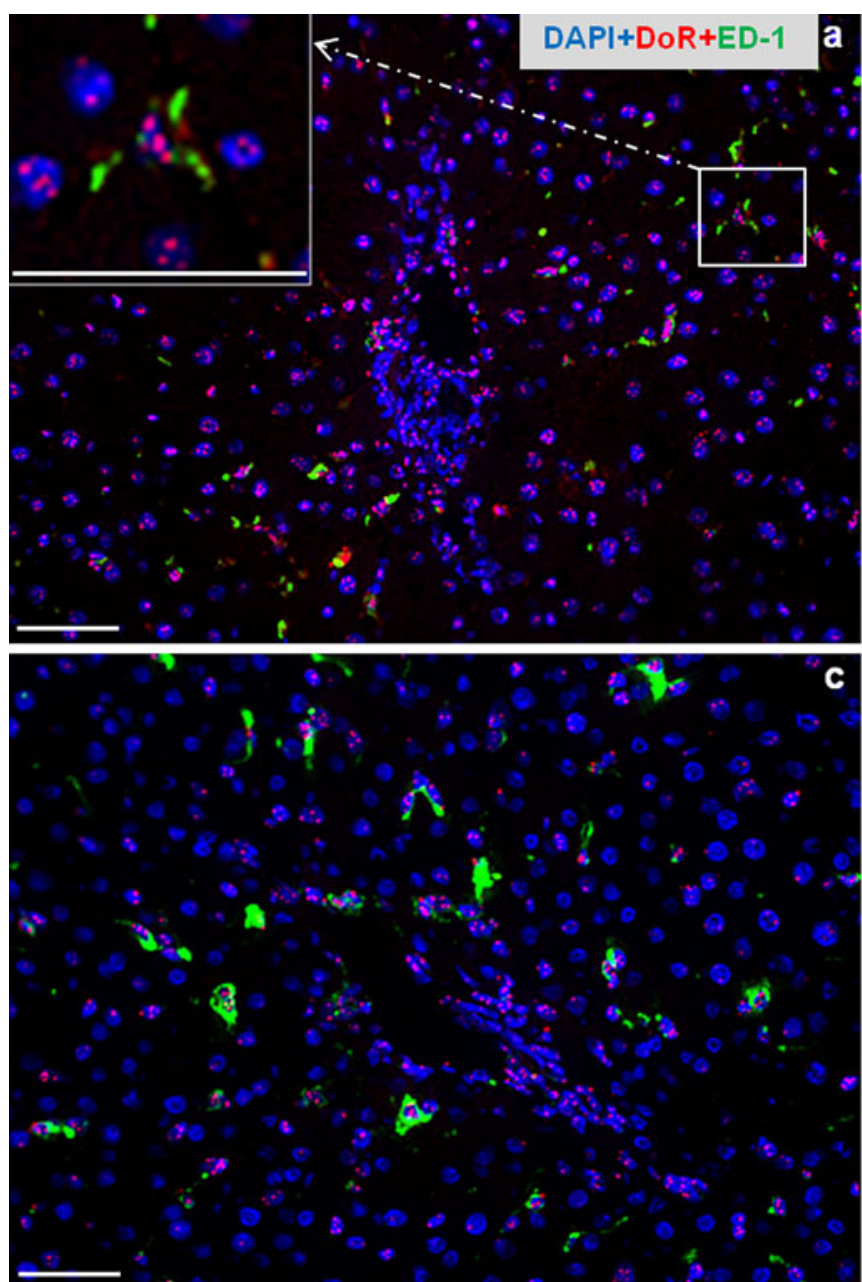

Fig. 4 Double-staining of liver sections with polyclonal antibody directed against DOR (red) and monoclonal antibody against human ED-1 (green) followed by fluorescent immunodetection in sections of rat liver during acute-phase response after TO treatment. a Control

\section{Results}

Changes in FT4 and FT3 serum levels in rats during APR

The FT3 serum level was significantly decreased below control values at $4 \mathrm{~h}$ after TO injection; this reduction lasted up to $72 \mathrm{~h}$ with a minimum of $60 \mathrm{~h}$. A similar pattern was also observed for FT4 at the serum level (Fig. 1a, b).

Subcellular DOR and TR $\alpha 1$ localisation in liver sections from untreated and APR animals

DOR protein was detected in the large nucleus of hepatocytes and was organized in well-defined spots, similar to that in HeLa cells (Baumgartner et al. 2007). The intensity of the DOR dots decreased 6-12 h after APR was initiated and began to increase thereafter (Fig. 2). Double-staining of biliary cells $\left(\mathrm{CK}-19^{+}\right)$, mesenchymal cells $\left(\mathrm{SMA}^{+}\right)$, and
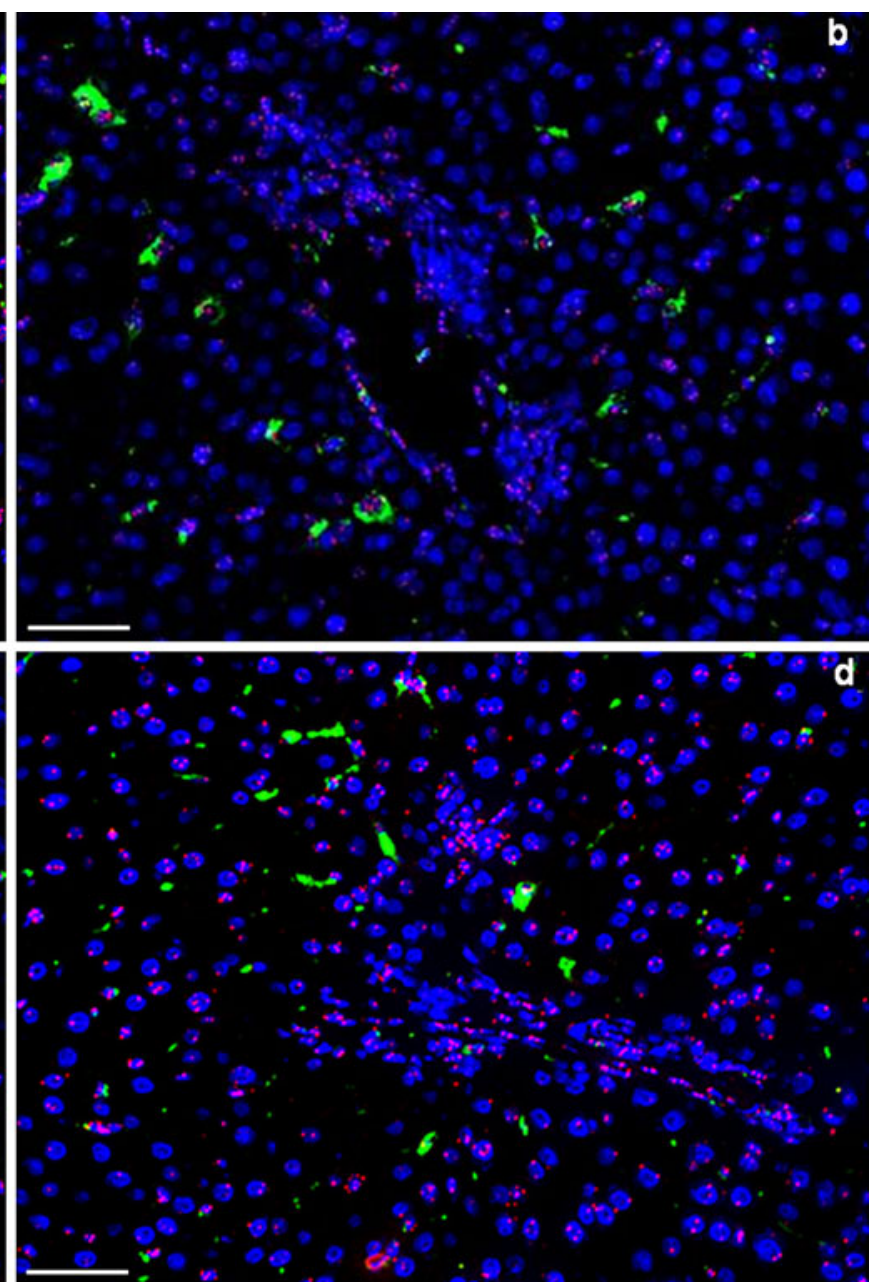

liver. Inset Higher magnification of boxed area in $\mathbf{a}$. b At $6 \mathrm{~h}$ after TO treatment. c At $12 \mathrm{~h}$ after TO treatment. d At 24 hours after TO treatment. Representive results from three animals and six slides per time-point. Original magnification: $\times 200$. Bars $100 \mu \mathrm{m}$ 
Fig. 5 Immunofluorescent staining of liver sections with polyclonal antibody directed against TR $\alpha 1$ (green) followed by fluorescence immunodetection in sections of rat liver during APR after TO treatment. $\mathbf{a}, \mathbf{c}, \mathbf{e}$ Control liver. $\mathbf{b}, \mathbf{d}, \mathbf{f}$ At $6 \mathrm{~h}$ after TO treatment. a, b Anti-TR $\alpha 1$ and 4,6-diamidino2-phenylindole (DAPI) staining (blue). c, d Anti-TR $\alpha 1$ staining. e, f DAPI staining. Insets Higher magnification of respective boxed areas. Inset in a AntiTR $\alpha 1$ and DAPI staining (arrows cells of portal area are also positive for TR $\alpha 1$ ). Inset in c Anti-TR $\alpha 1$ staining alone. Representive results from three animals and six slides per timepoint ( $P V$ portal vein, $C V$ central vein). Original magnification: $\times 200$. Bars $100 \mu \mathrm{m}$
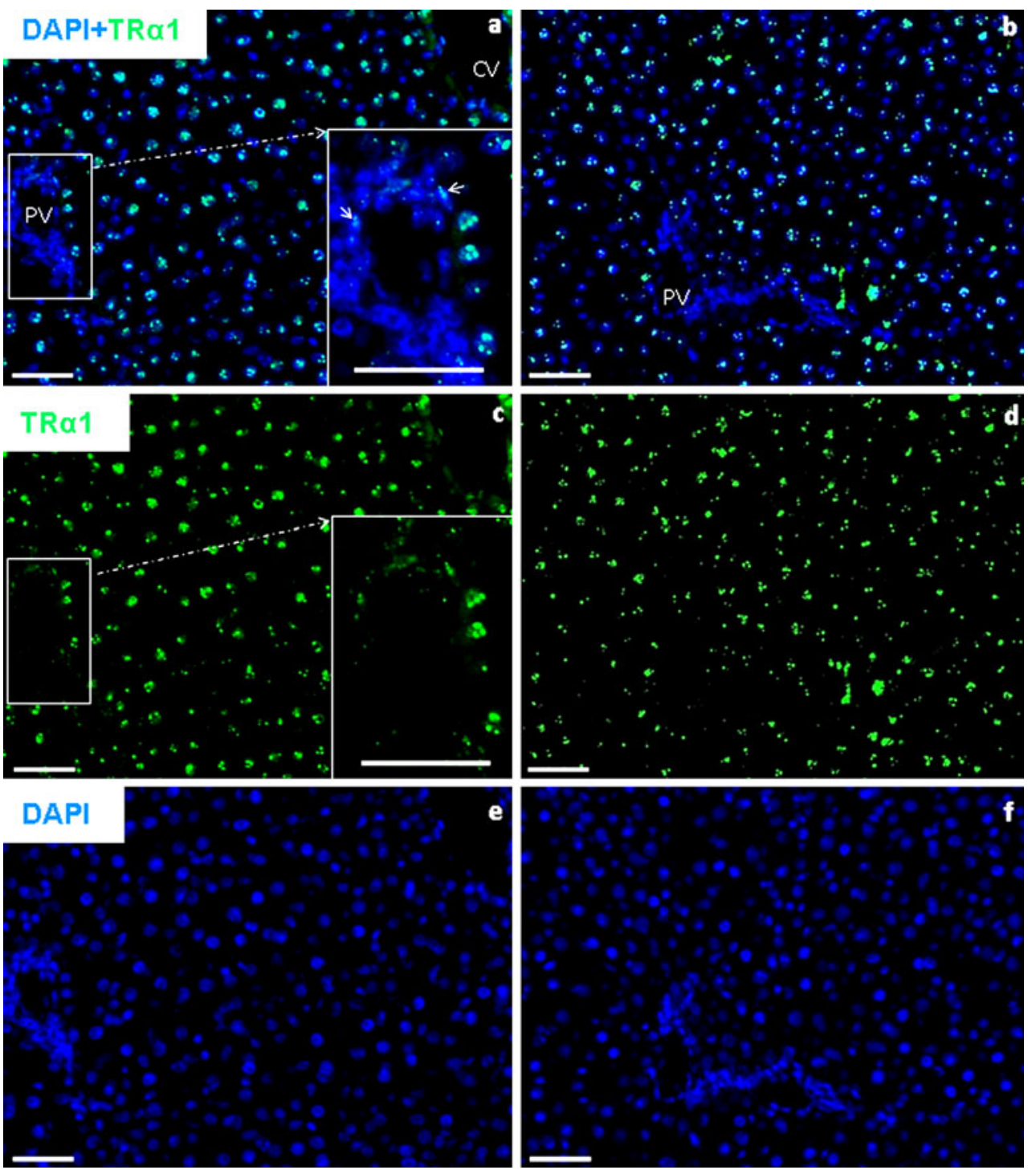

macrophages $\left(\mathrm{ED}-1^{+}\right)$also revealed DOR-positive dots in these cells. The intensity of dots decreased in CK-19 ${ }^{+}$cells, $\mathrm{SMA}^{+}$, and in ED- $1^{+}$cells during APR (Figs. 2, 3, 4).

Strong nuclear positivity for $\mathrm{TR} \alpha 1$ was found in liver sections from untreated animals and was evenly distributed in periportal and pericentral areas. In addition, positive dots were also noted around the cells of vessel walls of portal and central areas. Immunohistology revealed no significant change in the protein expression of TR $\alpha 1$ at any time-point during APR (Fig. 5a-f).

\section{DOR protein level in liver tissue during APR}

In accordance with the immunohistological detection, DOR protein levels decreased in nuclei during APR as detected by Western blot analysis of nuclear extracts. At the same time, the concentration of HO-1 protein, a positive control for APR, peaked at $12 \mathrm{~h}$ during APR, as previously described, confirming successful APR induction (Tron et al. 2005; Fig. 6a, b). a

HO-1

$\beta$-actin

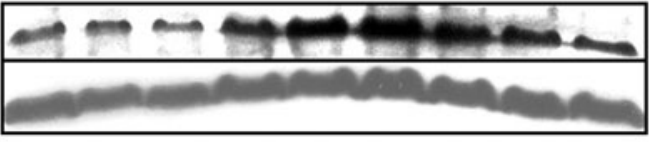

b

\section{DOR \\ $\beta$-actin}

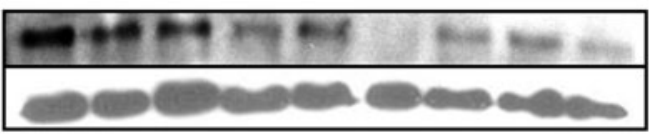

Fig. 6 Western blot analysis of protein from rat liver under APR conditions at various time-points with antibodies specific for (a) HO-1 and $\beta$-actin and for (b) DOR and $\beta$-actin using total protein and nuclear extract, respectively 
APR-induced changes of amount of TR transcripts in liver tissue

A decrease of DOR gene expression from $30 \mathrm{~min}$ to $24 \mathrm{~h}$, reaching a minimum at $6 \mathrm{~h}$, could be observed after the onset of the acute phase. Accordingly, a significant downregulation of NCoR-1-specific mRNA was found with a minimum at $6 \mathrm{~h}$ (Fig. 7a). TR $\beta 1$ was slightly up-regulated in the early phase followed by a significant downregulation with a minimum at $12 \mathrm{~h}$ and normalization of mRNA levels by $48 \mathrm{~h}$. A down-regulation was also observed in the later phase lasting up to the 72-h time- point. TR $\alpha 1$ steady state mRNA levels did not change during APR, whereas TR $\alpha 2$ showed significant upregulation, which peaked at $4 \mathrm{~h}$ after treatment followed by down-regulation with minimum expression $60 \mathrm{~h}$ after treatment (Fig. 7b).

Modulation of TR gene expression in cultured rat hepatocytes

DOR mRNA level in hepatocytes significantly decreased compared with untreated controls upon exposure to IL-6 or IL-1 $\beta$. The most pronounced decrease was observed at 6

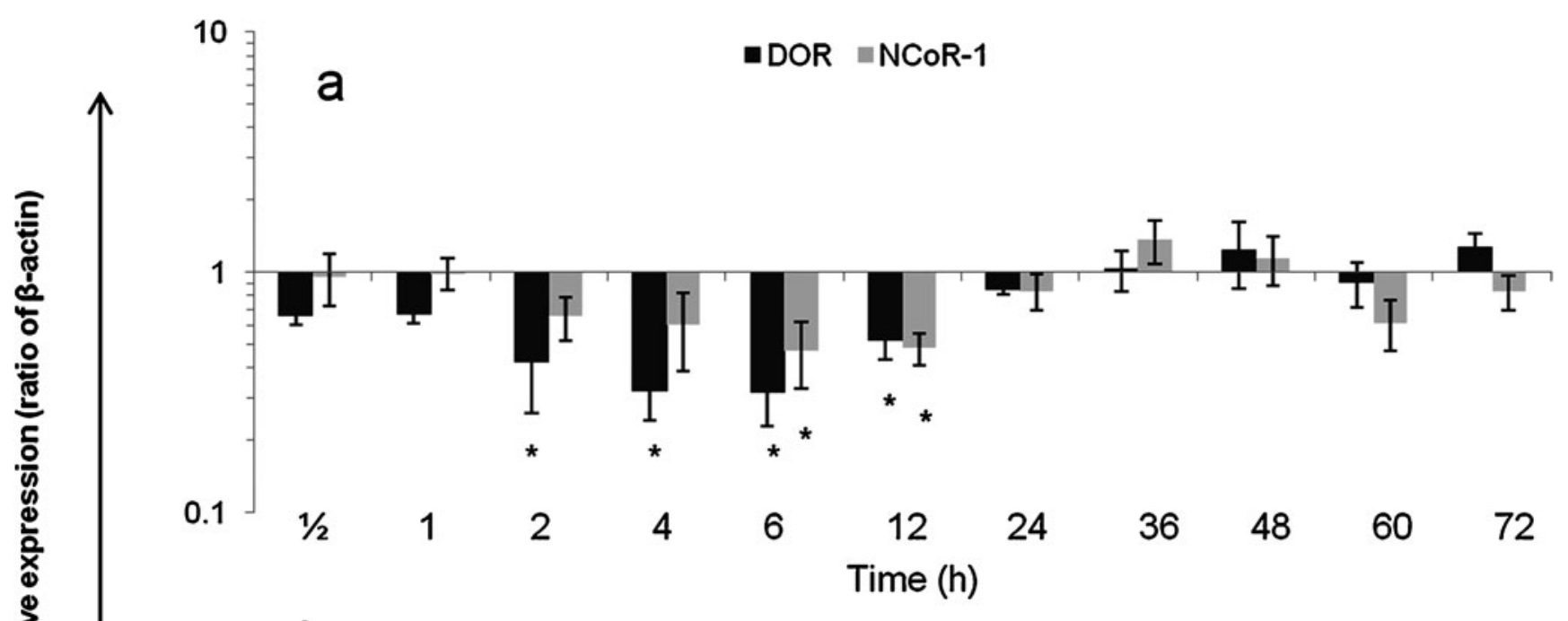

b

-TR-alpha1 -TR-alpha2 -TR-beta1

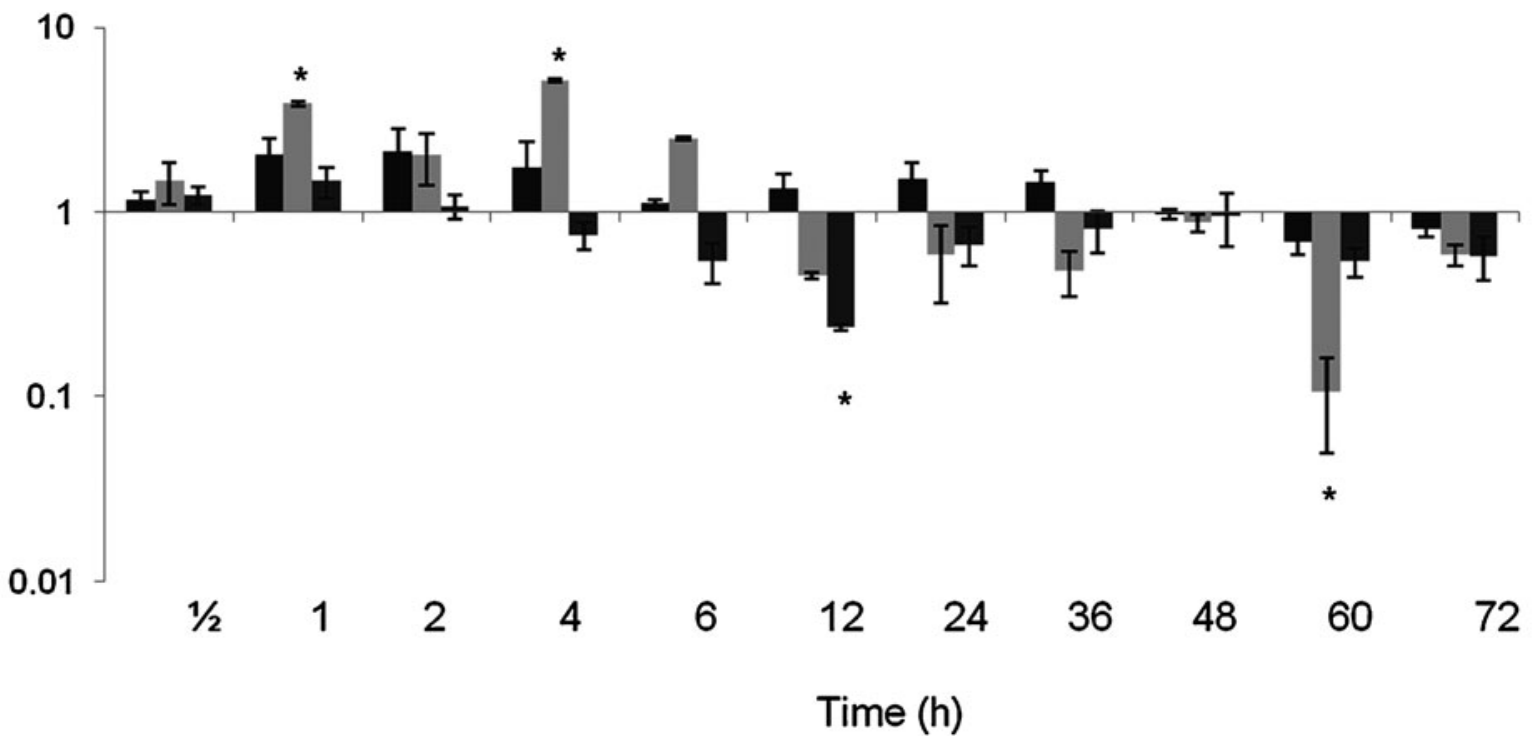

Fig. 7 Quantitative reverse transcription with polymerase chain reaction (qRT-PCR) analysis of total RNA from rat liver during APR. Fold-change in mRNA expression of DOR, NCoR1, TR $\alpha 1$, $\mathrm{TR} \alpha 2$, and $\mathrm{TR} \beta 1$ in the TO-treated liver at various time-points (1-
$72 \mathrm{~h})$ relative to saline-treated controls for each time-point. qRT-PCR was normalized by using two housekeeping genes: $\beta$-actin and ubiquitin $\mathrm{C}$. Results represent means \pm SEM of three animals; $* P<0.05$ 
and $12 \mathrm{~h}$ after the start of cytokine treatment. The effect of IL-6 on reducing DOR expression was stronger than that induced by IL-1 $\beta$ treatment. Similarly, an early (3-6 h) down-regulation of TR $\beta 1$ was also observed after treatment with IL- 6 or IL- $1 \beta$. The impact of IL- 6 was also stronger than IL- $1 \beta$ in cultured hepatocytes. No significant change in the gene expression of NCoR-1 was observed after IL-6 exposure; however, a rapid significant reduction (1-6 h) was detected after IL- $1 \beta$ treatment. In contrast, an early ( $1 \mathrm{~h}$ ) up-regulation of TR $\alpha 1$ and TR $\alpha 2$ was observed after treatment with IL-6 followed by a slight down-regulation thereafter. Surprisingly, a fast down-regulation ( $1 \mathrm{~h})$ of both genes was detected followed by up-regulation at 3-6 $\mathrm{h}$ in hepatocytes when treated with IL-1 $\beta$ (Figs. 8, 9).
T3 treatment of hepatocytes significantly induced early gene expression of DOR, NCoR-1, and TR $\alpha 1$ and this steadily increased with a maximum at $24 \mathrm{~h}$. An early significant up-regulation at $1 \mathrm{~h}$ was also detected for the gene expression of $\operatorname{TR} \alpha 2$ and TR $\beta 1$ with a maximum of induction at $12 \mathrm{~h}$. The up-regulating effect was completely cancelled by the addition of IL- 6 to the culture medium (Fig. 8).

\section{Discussion}

In the present study, we investigated the expression levels of key receptors of the THs mainly responsible for hormone
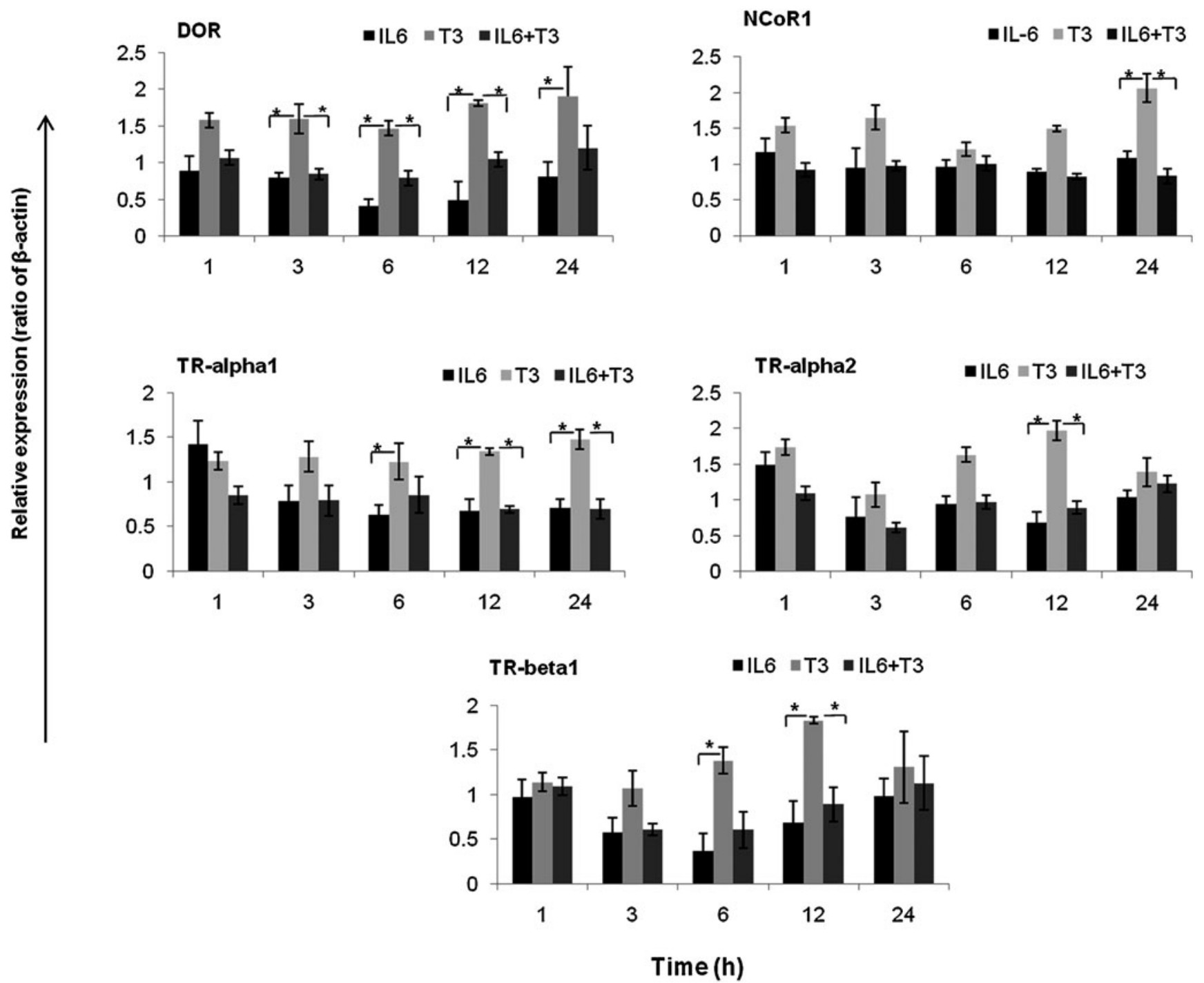

Fig. 8 qRT-PCR analysis of total RNA from isolated rat hepatocytes treated with IL-6, T3, or IL-6+T3. Data are shown as fold-changes in mRNA expression of DOR, NCoR-1, TR $\alpha 1, \mathrm{TR} \alpha 2$, and TR $\beta 1$ at various time-points relative to untreated controls for each time-point.
qRT-PCR was normalized by using two housekeeping genes: $\beta$-actin and ubiquitin $\mathrm{C}$. Results represent means \pm SEM of three experiments; $* P<0.05$ 
Fig. 9 qRT-PCR analysis of total RNA from isolated rat hepatocytes treated with IL-1 $\beta$. Data are shown as fold-changes in mRNA expression of DOR, NCoR-1, TR $\alpha 1, T R \alpha 2$, and $\mathrm{TR} \beta 1$ at various time-points relative to untreated controls for each time-point. qRT-PCR was normalized by using two housekeeping genes: $\beta$-actin and ubiquitin C. Results represent means \pm SEM of three experiments; ${ }^{*} P<0.05$

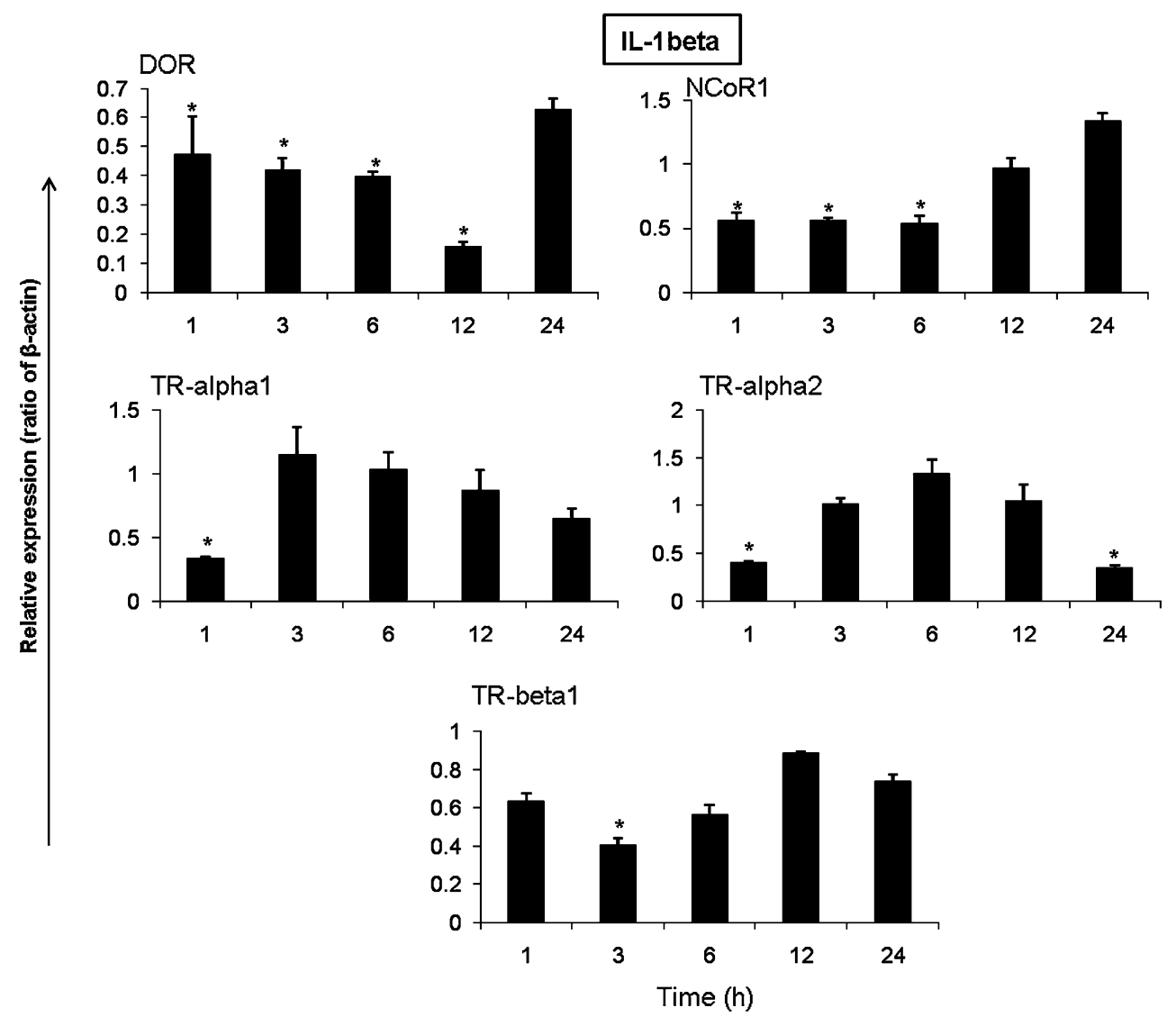

signaling, namely $\mathrm{TR} \alpha 1, \mathrm{TR} \alpha 2, \mathrm{TR} \beta 1, \mathrm{NCoR}-1$, and the newly identified TR cofactor DOR/TP53INP2, in the rat liver during APR in parallel with the serum level of the THs. In isolated hepatocytes treated with acute-phase mediators, with or without TH, we also studied changes of TR gene expression. The results of the current study demonstrate that hepatocytes, macrophages, mesenchymal cells, and bile duct cells express abundant amounts of nuclear DOR with a decrease during the first 6-24 h of APR. In contrast, TR $\alpha 1$ immunoreactivity shows a uniform, equally distributed, and constant nuclear positivity throughout the liver. In accordance with the immunohistology and Western blot analysis, DOR gene expression is also down-regulated at the mRNA level in the liver. Commensurate with the down-regulation observed for the DOR gene, similar patterns of expression have been detected for TR $\beta 1$ and NCoR-1 at the mRNA level, whereas $\mathrm{TR} \alpha 1$ is only slightly up-regulated, and $\mathrm{TR} \alpha 2$ is significantly up-regulated during APR.

To address the question of whether the reduction in DOR and TR $\beta 1$ gene expression during APR might have also been attributable to the direct effect of acute-phase mediators (IL-6 and IL-1 $\beta$ ) on the genes studied, a major population of the liver cells (hepatocytes) was isolated and treated with two "major" acute-phase cytokines (IL-6 and IL-1 $\beta$ ). Similar to the observations in the liver tissue during APR, a reduction in gene expression of DOR and TR $\beta 1$ was found after treatment with acute-phase cytokines (IL-6 and IL-1 $\beta$ ). Likewise, an up-regulation of $\operatorname{TR} \alpha 1$ and the negative factor TR $\alpha 2$ was also observed. Whereas treatment of hepatocytes with T3 increased the gene expression of DOR and of the other TRs, such an increase was inhibited completely by the addition of IL-6 to the culture medium.

THs are known to regulate gene expression through receptors (TRs: TR $\alpha$ and $\operatorname{TR} \beta$ ), and changes in their gene expression are accompanied by progressive changes in $\mathrm{TH}$ level (Brent et al. 1989b).

Our current study has shown that transcription of T3controlled TR genes is severely affected during APR; this might be more dependent on cytokines and the TH level than on the TH level alone. The association between acutephase cytokines and TH might entail a causal link, as we have found that the T3 signaling molecules TR $\beta 1$, DOR, and NCoR1 are down-regulated in the liver during APR, whereas the negative signaling factor $\mathrm{TR} \alpha 2$ is up-regulated. Tissue injury induces an acute-phase response, which is a major mechanism of the body to restore homeostasis; APR is heavily regulated by inflammatory cytokines such as IL-6 (Ramadori and Christ 1999; Sheikh et al. 2006) and is negatively related to serum T3 levels (Bartalena et al. 1994). Thus, the involvement of acute-phase cytokines in the pathogenesis of APR classifies NTI as part of the acutephase response. 
In other words, the decrease in TR $\beta 1$ and in the expression of the newly identified gene DOR is attributable not only to the decrease in TH serum concentration, but possibly also to the direct effect of acute-phase cytokines produced during APR on hepatocytes. Our study is moreover the first to show that the expression of the newly identified gene DOR is similar to that of the major TR, viz., $\mathrm{TR} \beta 1$, in rat liver under APR.

The gene expression of TRs in NTI has been partially described in previous studies. However, the clinical impact, with a comprehensive study of major TRs, including the newly identified gene DOR, under acutephase conditions has not been previously established. Furthermore, previous reports examining the changes in expression of TRs in models of NTI also show somewhat conflicting findings.

Boelen et al. (2006) have reported a rapid decrease in liver TR $\beta 1$ mRNA after lipopolysaccharide (LPS) administration in an animal model of APR. A lowering of TR $\beta 1$ mRNA in response to IL-1 $\beta$ also occurs in vitro in a hepatoma cell line (Kwakkel et al. 2006). In the rabbit model of prolonged ( 7 days) burn injury, TRs are unchanged in the hypothalamus-pituitary-thyroid axis (Mebis et al. 2009).

In contrast to treatments inducing an acute systemic response and also liver damage, such as the administration of the bacterial endotoxin LPS (Boelen et al. 2006), TO is known to induce aseptic local abscesses without detectable injury to other tissues (Ramadori and Meyer Zum Buschenfelde 1990; Tron et al. 2005; Wusteman et al. 1990). Therefore, the TO-induced APR model allows us to study the effect of cytokines produced at distant sites to the liver. It reproduces the changes observed in human disease states caused by localized tissue injury (Gabay and Kushner 1999; Halter et al. 2005; Kim et al. 2002; Stoeck et al. 2006) making it an ideal model for studying human APR. Use of this model in the current study is also of special interest as the down-regulation of TR $\beta 1$ and up-regulation of TR $\alpha 2$ have been observed, which might be attributable to the inhibitory effect of TR $\alpha 2$ on TR $\beta 1$, as previously reported (Koenig et al. 1989). This fact has not been reported in any other acute-phase animal model so far.

In conclusion, our data suggest that therapeutic replacement under acute-phase conditions might not be effective, as activating TRs are not available, and their inhibitor $(\mathrm{TR} \alpha 2)$ is up-regulated at the same time.

Open Access This article is distributed under the terms of the Creative Commons Attribution Noncommercial License which permits any noncommercial use, distribution, and reproduction in any medium, provided the original author(s) and source are credited.

\section{References}

Amma LL, Campos-Barros A, Wang Z, Vennstrom B, Forrest D (2001) Distinct tissue-specific roles for thyroid hormone receptors beta and alphal in regulation of type 1 deiodinase expression. Mol Endocrinol 15:467-475

Bartalena L, Brogioni S, Grasso L, Velluzzi F, Martino E (1994) Relationship of the increased serum interleukin- 6 concentration to changes of thyroid function in nonthyroidal illness. J Endocrinol Invest 17:269-274

Baumgartner BG, Orpinell M, Duran J, Ribas V, Burghardt HE, Bach D, Villar AV, Paz JC, Gonzalez M, Camps M, Oriola J, Rivera F, Palacin M, Zorzano A (2007) Identification of a novel modulator of thyroid hormone receptor-mediated action. PLoS ONE 2: e1183

Becker RA, Vaughan GM, Ziegler MG, Seraile LG, Goldfarb IW, Mansour EH, McManus WF, Pruitt BA Jr, Mason AD Jr (1982) Hypermetabolic low triiodothyronine syndrome of burn injury. Crit Care Med 10:870-875

Boelen A, Kwakkel J, Wiersinga WM, Fliers E (2006) Chronic local inflammation in mice results in decreased TRH and type 3 deiodinase mRNA expression in the hypothalamic paraventricular nucleus independently of diminished food intake. J Endocrinol 191:707-714

Brent GA, Hershman JM (1986) Thyroxine therapy in patients with severe nonthyroidal illnesses and low serum thyroxine concentration. J Clin Endocrinol Metab 63:1-8

Brent GA, Harney JW, Chen Y, Warne RL, Moore DD, Larsen PR (1989a) Mutations of the rat growth hormone promoter which increase and decrease response to thyroid hormone define a consensus thyroid hormone response element. Mol Endocrinol 3:1996-2004

Brent GA, Larsen PR, Harney JW, Koenig RJ, Moore DD (1989b) Functional characterization of the rat growth hormone promoter elements required for induction by thyroid hormone with and without a co-transfected beta type thyroid hormone receptor. J Biol Chem 264:178-182

Chirgwin JM, Przybyla AE, MacDonald RJ, Rutter WJ (1979) Isolation of biologically active ribonucleic acid from sources enriched in ribonuclease. Biochemistry 18:5294-5299

Dace A, Zhao L, Park KS, Furuno T, Takamura N, Nakanishi M, West BL, Hanover JA, Cheng S (2000) Hormone binding induces rapid proteasome-mediated degradation of thyroid hormone receptors. Proc Natl Acad Sci USA 97:8985-8990

De Groot LJ (1999) Dangerous dogmas in medicine: the nonthyroidal illness syndrome. J Clin Endocrinol Metab 84:151-164

Dijkstra CD, Dopp EA, Joling P, Kraal G (1985) The heterogeneity of mononuclear phagocytes in lymphoid organs: distinct macrophage subpopulations in the rat recognized by monoclonal antibodies ED1, ED2 and ED3. Immunology 54:589599

Ercan-Fang S, Schwartz HL, Oppenheimer JH (1996) Isoform-specific $3,5,3$ '-triiodothyronine receptor binding capacity and messenger ribonucleic acid content in rat adenohypophysis: effect of thyroidal state and comparison with extrapituitary tissues. Endocrinology 137:3228-3233

Fowden AL (1995) Endocrine regulation of fetal growth. Reprod Fertil Dev 7:351-363

Gabay C, Kushner I (1999) Acute-phase proteins and other systemic responses to inflammation. N Engl J Med 340:448-454

Grignani F, De MS, Nervi C, Tomassoni L, Gelmetti V, Cioce M, Fanelli M, Ruthardt M, Ferrara FF, Zamir I, Seiser C, Grignani F, Lazar MA, Minucci S, Pelicci PG (1998) Fusion proteins of the retinoic acid receptor-alpha recruit histone deacetylase in promyelocytic leukaemia. Nature 391:815-818 
Halter J, Steinberg J, Fink G, Lutz C, Picone A, Maybury R, Fedors N, DiRocco J, Lee HM, Nieman G (2005) Evidence of systemic cytokine release in patients undergoing cardiopulmonary bypass. J Extra-Corpor Technol 37:272-277

Horlein AJ, Naar AM, Heinzel T, Torchia J, Gloss B, Kurokawa R, Ryan A, Kamei Y, Soderstrom M, Glass CK (1995) Ligandindependent repression by the thyroid hormone receptor mediated by a nuclear receptor co-repressor. Nature 377:397-404

Kim YI, Song KE, Ryeon HK, Hwang YJ, Yun YK, Lee JW, Chun BY (2002) Enhanced inflammatory cytokine production at ischemia/reperfusion in human liver resection. Hepatogastroenterology 49:1077-1082

Koenig RJ, Lazar MA, Hodin RA, Brent GA, Larsen PR, Chin WW, Moore DD (1989) Inhibition of thyroid hormone action by a nonhormone binding c-erbA protein generated by alternative mRNA splicing. Nature 337:659-661

Kwakkel J, Wiersinga WM, Boelen A (2006) Differential involvement of nuclear factor-kappaB and activator protein-1 pathways in the interleukin-1beta-mediated decrease of deiodinase type 1 and thyroid hormone receptor beta1 mRNA. J Endocrinol 189:37-44

Laemmli UK (1970) Cleavage of structural proteins during the assembly of the head of bacteriophage T4. Nature 227:680-685

Laudet V, Begue A, Henry-Duthoit C, Joubel A, Martin P, Stehelin D, Saule S (1991) Genomic organization of the human thyroid hormone receptor alpha (c-erbA-1) gene. Nucleic Acids Res 19:1105-1112

Macchia PE, Takeuchi Y, Kawai T, Cua K, Gauthier K, Chassande O, Seo H, Hayashi Y, Samarut J, Murata Y, Weiss RE, Refetoff S (2001) Increased sensitivity to thyroid hormone in mice with complete deficiency of thyroid hormone receptor alpha. Proc Natl Acad Sci USA 98:349-354

Malik IA, Moriconi F, Sheikh N, Naz N, Khan S, Dudas J, Mansuroglu T, Hess CF, Rave-Frank M, Christiansen H, Ramadori G (2010) Single-dose gamma-irradiation induces upregulation of chemokine gene expression and recruitment of granulocytes into the portal area but not into other regions of rat hepatic tissue. Am J Pathol 176:1801-1815

Mebis L, Debaveye Y, Ellger B, Derde S, Ververs EJ, Langouche L, Darras VM, Fliers E, Visser TJ, Van den Berghe G (2009) Changes in the central component of the hypothalamus-pituitary-thyroid axis in a rabbit model of prolonged critical illness. Crit Care 13:R147

Pierzchalski P, Rokita H, Koj A, Fries E, Akerstrom B (1992) Synthesis of alpha 1-microglobulin in cultured rat hepatocytes is stimulated by interleukin-6, leukemia inhibitory factor, dexamethasone and retinoic acid. FEBS Lett 298:165-168

Ramadori G, Christ B (1999) Cytokines and the hepatic acute-phase response. Semin Liver Dis 19:141-155

Ramadori G, Meyer Zum Buschenfelde KH (1990) The acute phase reaction and its mediators. II. Alpha tumor necrosis factor and interleukin 6. Z Gastroenterol 28:14-21
Ramadori G, Sipe JD, Colten HR (1985a) Expression and regulation of the murine serum amyloid A (SAA) gene in extrahepatic sites. J Immunol 135:3645-3647

Ramadori G, Sipe JD, Dinarello CA, Mizel SB, Colten HR (1985b) Pretranslational modulation of acute phase hepatic protein synthesis by murine recombinant interleukin 1 (IL-1) and purified human IL-1. J Exp Med 162:930-942

Ramadori G, Moebius U, Dienes HP, Meuer S, Meyer Zum Buschenfelde KH (1990) Lymphocytes from hepatic inflammatory infiltrate kill rat hepatocytes in primary culture. Comparison with peripheral blood lymphocytes. Virchows Arch B Cell Pathol Mol Pathol 59:263-270

Seglen PO (1972) Preparation of rat liver cells. I. Effect of $\mathrm{Ca}^{2+}$ on enzymatic dispersion of isolated, perfused liver. Exp Cell Res 74:450-454

Sheikh N, Tron K, Dudas J, Ramadori G (2006) Cytokine-induced neutrophil chemoattractant-1 is released by the noninjured liver in a rat acute-phase model. Lab Invest 86:800-814

Stoeck K, Bodemer M, Zerr I (2006) Pro- and anti-inflammatory cytokines in the CSF of patients with Creutzfeldt-Jakob disease. J Neuroimmunol 172:175-181

Towbin H, Staehelin T, Gordon J (1979) Electrophoretic transfer of proteins from polyacrylamide gels to nitrocellulose sheets: procedure and some applications. Proc Natl Acad Sci USA 76:4350-4354

Tron K, Novosyadlyy R, Dudas J, Samoylenko A, Kietzmann T, Ramadori G (2005) Upregulation of heme oxygenase-1 gene by turpentine oil-induced localized inflammation: involvement of interleukin-6. Lab Invest 85:376-387

Van den Berghe G, Wouters P, Weekers F, Mohan S, Baxter RC, Veldhuis JD, Bowers CY, Bouillon R (1999) Reactivation of pituitary hormone release and metabolic improvement by infusion of growth hormone-releasing peptide and thyrotropinreleasing hormone in patients with protracted critical illness. J Clin Endocrinol Metab 84:1311-1323

Van den Berghe G, Baxter RC, Weekers F, Wouters P, Bowers CY, Iranmanesh A, Veldhuis JD, Bouillon R (2002) The combined administration of GH-releasing peptide-2 (GHRP-2), TRH and GnRH to men with prolonged critical illness evokes superior endocrine and metabolic effects compared to treatment with GHRP-2 alone. Clin Endocrinol (Oxf) 56:655-669

Ventura-Holman T, Mamoon A, Maher JF, Subauste JS (2007) Thyroid hormone responsive genes in the murine hepatocyte cell line AML 12. Gene 396:332-337

Wusteman M, Wight DG, Elia M (1990) Protein metabolism after injury with turpentine: a rat model for clinical trauma. Am J Physiol 259:E763-E769

Yen PM (2001) Physiological and molecular basis of thyroid hormone action. Physiol Rev 81:1097-1142 